\title{
Scrotal Tissue Necrosis in a Patient with Urethral Stricture Treated with Internal Urethrotomy and Mitomycin-C Injection
}

\section{Üretra Darlığı Nedeniyle Internal Üretrotomi ve Mitomisin-C Enjeksiyonu ile Tedavi Edilen Bir Hastada Gelişen Skrotal Doku Nekrozu}

\author{
(D) Bahadır Topuz1', (1) Sercan Yılmaz², (1) Sami Uğuz', (1) Hasan Cem Irkılata3 \\ 1 University of Health Sciences, Gülhane Research and Training Hospital, Clinic of Urology, Ankara, Turkiye \\ 2Niğde Bor State Hospital, Clinic of Urology, Niğde, Turkiye \\ ${ }^{3}$ Davraz Yaşam Hospital, Clinic of Urology, Isparta, Turkiye
}

\begin{abstract}
An 89-year-old male patient was admitted with open scrotal tissue wound. Approximately $4 \times 4 \mathrm{~cm}$ scrotal necrotic tissue extending to the anal region was observed. It was learned that the patient underwent radical prostatectomy 9 years ago and then, internal urethrotomy was performed due to urethral stricture. Urethroscopy showed an anterior urethral stricture $2 \mathrm{~cm}$ in length. After internal urethrotomy, $20 \mathrm{mg}$ of mitomycin-C (MMC) was diluted with $50 \mathrm{cc}$ saline and injected as an intralesional injection (10 cc) and instillation (40 cc). In previous applications, our patients have tolerated this treatment during the process. In this case report, we present the case of scrotal tissue necrosis and treatment in a patient in whom internal urethrotomy and intralesional MMC application were performed.
\end{abstract}

Keywords: Collagen, Internal urethrotomy, Mitomycin-C, Necrosis, Urethral stricture

Öz

Seksen dokuz yaşında erkek hasta skrotal bölgede açık yara ile başvurdu. Skrotal bölgeden anal bölgeye doğru uzanan yaklaşık 4x4 cm'lik nekrotik doku izlendi. Dokuz yı önce radikal prostatektomi olduğu ve sonra üretra darlığı nedeniyle internal üretrotomi olduğu öğrenildi. Üretroskopisinde 2 $\mathrm{cm}$ uzunluğunda anterior üretral darlık saptandı. İnternal üretrotomi sonrası, $20 \mathrm{mg}$ mitomisin-C (MMC), 50 cc salinle dilüe edildi ve intralezyonel (10 cc) ve instilasyon (40 cc) tarzında uygulandı. Önceki uygulamalarda hastalar bu tedaviyi iyi tolere etmişlerdi. Bu olgu sunumunda, internal üretrotomi ve intralezyonel MMC uygulanan bir hastadaki skrotal doku nekrozunu ve tedavisini sunduk.

Anahtar Kelimeler: Kolajen, İnternal üretrotomi, Mitomisin-C, Nekroz, Üretra darlığı

\section{Introduction}

Urethral strictures are one of the most difficult urological problems in terms of treatment. Trauma and iatrogenic factors are more frequently observed in the etiology (1). Various treatment techniques have been developed for the treatment of urethral stricture, depending on the length of the stenosis, location and depth of scarring (2). According to the International Consultation on Urological Diseases and American Urological Association Guidelines, simple urethral dilatation, direct visual internal urethrotomy, laser urethrotomy, anterior urethral stenting or urethroplasty can be performed for bulbar urethral strictures of $<2 \mathrm{~cm}(3,4)$. Urethral dilatation and cold knife urethrotomy are the safest therapy procedures for short urethral strictures, with a total success rate of $35-70 \%$ (3). The success rate for this treatment is very low when the size of the stenotic segment is longer than $2 \mathrm{~cm}$ (3). Urethral catheter can be safely removed within 24-72 hours following direct visual internal urethrotomy. Surgeons may offer self-catheterization schedules after direct visual internal urethrotomy for maintaining temporary urethral patency in candidates for urethoplasty (3). The success rate for resection and primary anastomosis of

Correspondence: Bahadır Topuz MD, University of Health Sciences, Gülhane Research and Training Hospital, Clinic of Urology, Ankara, Turkiye Phone: +90 3123045607 E-mail: drbtopuz@gmail.com ORCID-ID: orcid.org/0000-0001-6209-803X

Received: 17.10.2017 Accepted: 07.12.2017

Cite this article as: Topuz B, Yılmaz S, Uğuz S, Irkılata HC. Scrotal Tissue Necrosis in a Patient with Urethral Stricture Treated with Internal Urethrotomy and Mitomycin-C Injection. J Urol Surg 2018;5(4):217-220.

๑Copyright 2018 by the Association of Urological Surgery / Journal of Urological Surgery published by Galenos Publishing House. 
the stenotic segment is higher than for endoscopic treatment for bulbar urethral stricture (3). However, urethroplasty is a surgical procedure associated with high morbidity compared to endoscopic treatment. Urethroplasty should be performed for recurrent anterior urethral strictures following failed dilatation or endoscopic treatment (3). Surgeons should offer urethroplasty for a long $(\geq 2 \mathrm{~cm})$ bulbar urethral strictue. Urethral stenting may be performed in patients not suitable for urethroplasty (4). Injection of an antiproliferative agent injection, such as mitomycin-C (MMC), is a feasible method despite the conflicting data regarding the treatment of recurrent urethral stricture $(3,4)$.

MMC is used in the treatment of superficial bladder cancer and it reduces tumor recurrence when administered intravesically after transurethral bladder resection (5). Recurrence of the stricture after internal urethrotomy is associated with poor prognosis in some patients. Therefore, MMC has been used as an instillation or intralesional injection during internal urethrotomy. It has been reported that submucosal injection of MMC during internal urethrotomy reduced stricture recurrence (6). In previous years, patients have endured adverse events associated with MMC administration.

In this case, we report a case of scrotal necrosis in a patient who was treated with MMC administration following cold knife urethrotomy for urethral stenosis.

\section{Case Presentation}

An 89-year-old male patient presented with tissue necrosis in the inferior hemiscrotum. It was seen that the lesion infiltrated into the subcutaneous tissue (Figure 1). The patient has been diagnosed with prostate cancer 9 years ago and open radical prostatectomy was performed. Internal urethrotomy and urethral dilatation had been performed several times within 1 year due to urethral stricture after radical prostatectomy.

In his urethroscopy, anterior urethral stricture $2 \mathrm{~cm}$ in length was determined. After internal urethrotomy, $20 \mathrm{mg}$ of MMC was diluted with $50 \mathrm{cc}$ isotonic solution and applied as an intralesional injection $(10 \mathrm{cc}$ ) and instillation (40 cc). An 18Fr Foley catheter was placed after the surgery. The catheter was removed on the postoperative $10^{\text {th }}$ day and there was no problem during micturition. On the $15^{\text {th }}$ postoperative day, epididymo-orchitis was detected and antibiotic treatment was planned.

On the postoperative first month, there was scrotal necrosis, but urethral stenosis was not detected in his urethroscopy. Debridement surgery was planned and the necrotic tissue was resected from the scrotal region. No necrotic tissue was observed in the testes and anal region. Postoperative hyperbaric oxygen treatment was considered but not applied because of claustrophobia. In postoperative $3^{\text {rd }}$ month, there was no necrotic tissue in the scrotal area (Figure 2). The urethral stricture recurred about 1 year after the last operation and the perineal urethrostomy was performed and routine follow-up was planned.

Written informed consent was obtained from the patient.

\section{Discussion}

MMC is an alkylating drug preventing DNA synthesis and is known to be effective against gastrointestinal, lung, uterine, head-neck, and bladder cancers, and chronic leukemia. It is known that it reduces the risk of recurrence of bladder cancer. The most frequent adverse event is chemical cystitis after intravesical administration, which occurs in approximately 0-39\% of patients (7). In vitro and animal model studies have shown that MMC decreases the collagen accumulation and scar formation by hindering fibroblast proliferation (8). MMC has been described as an anti-fibroblast effective agent and for this reason, MMC injection has emerged as a preferred treatment procedure for urethral strictures and bladder neck contractures $(6,9,10,11)$.

In a study performed by Vanni et al. (9), favorable results were obtained with internal urethrotomy and intralesional MMC administration in recurrent bladder neck contractures. No complication was observed after MMC administration. Mazdak et al. (6) found that sub-mucosal injection of MMC resulted in a significant decrease in recurrence of stricture. They described MMC injection as a safe and easy method in the treatment of urethral stricture. Intralesional triamcinolone, MMC and hyaluronidase injections were performed with internal urethrotomy for the treatment of anterior urethral stricture in 2014 (10). Injection of these three agents increased the effectiveness of internal urethrotomy with no regional or systemic adverse events. Sourial et al. (12) performed MMC injection with urethral dilatation for the treatment of recurrent vesicourethral anastomotic stricture after radical prostatectomy and they did not notice any adverse effects. They found that MMC injection with urethral dilatation was a reliable, efficient, and minimally invasive treatment method. Redshaw et al. (13) reviewed data on 55 patients with bladder neck obstruction who underwent bladder neck resection with MMC injection. They reported that $7 \%$ of patients $(n=4)$ experienced serious adverse effects, including osteitis pubis, necrosis of the trigone and genesis of rectourethral fistula. The exact mechanism of these adverse events associated with MMC injection was not understood. Moradi et al. (14) found that internal urethrotomy and application of MMC hydrogel might have an anti-fibrotic action preventing post-traumatic anterior urethral stricture recurrence with no adverse events. Kumar et al. (15) evaluated 


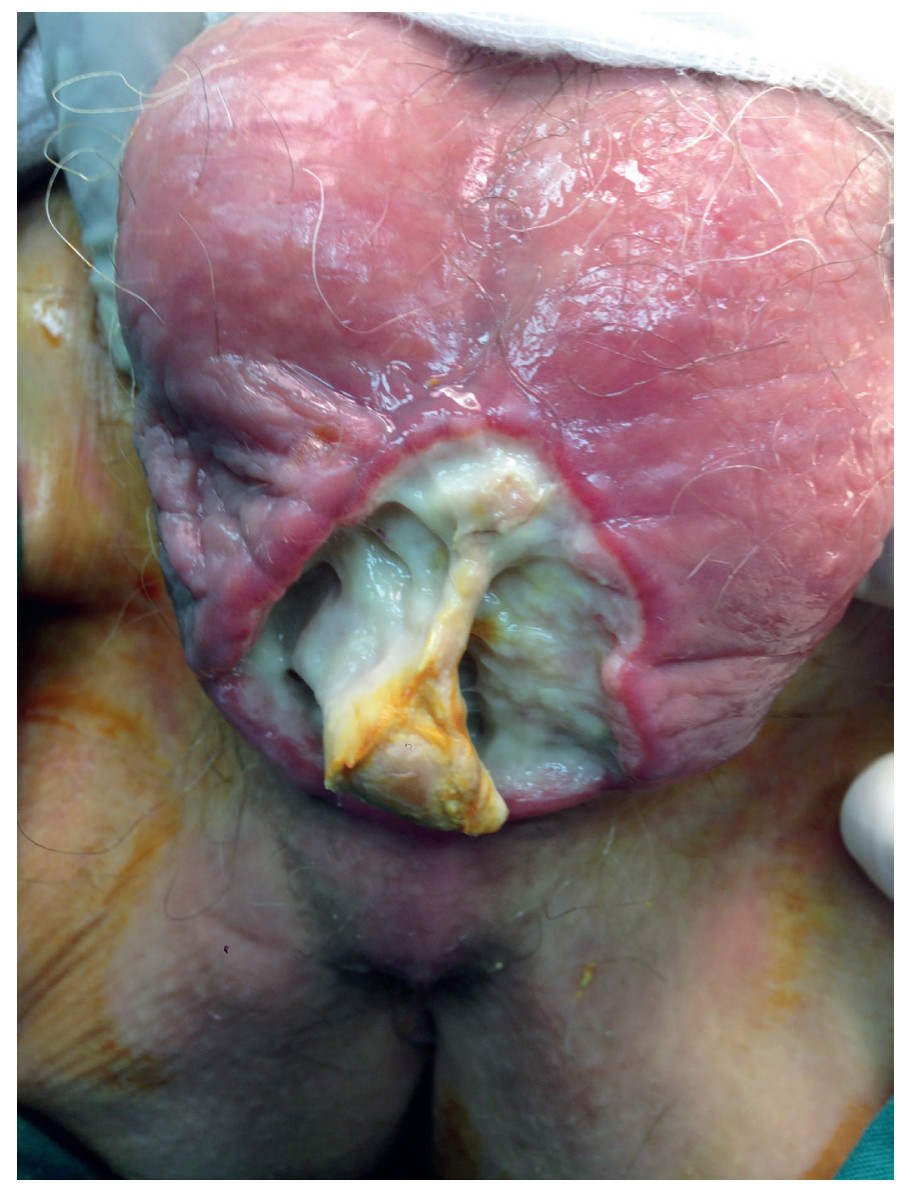

Figure 1. Approximately $4 \times 4 \mathrm{~cm}$ scrotal necrotic tissue extending to the anal region was observed

the influence of holmium laser urethrotomy with intralesional administration of Santosh PGI tetra-inject (triamcinolone, MMC, hyaluronidase and $\mathrm{N}$-acetyl cysteine) in 50 patients with urethral stricture. They reported a successful outcome in 41 patients (82\%) (15). A total of 50 patients were cured with this method. No complications were observed after intralesional injection of Santosh PGI tetra-inject. Ali et al. (16) reported effectiveness of MMC in avoiding urethral stricture recurrence after internal urethrotomy without any major complications such as necrosis of the urothelium, extravasation, or systemic absorption.

The urethra is endoscopically incised in some operations such as internal urethrotomy. If the incision involves a deep or wide urethral segment, the integrity of the spongious body may be impaired and the irrigation fluid may leak into the tissues. Then the irrigation fluid passes through the tissues to the vascular area and can initiate an infective process in adjacent organs. In our case, MMC was applied as an intralesional injection and instillation after the urethral incision. After this procedure, the solution which contained MMC was probably spread into the tissues and initiated an infective process. The clinical situation

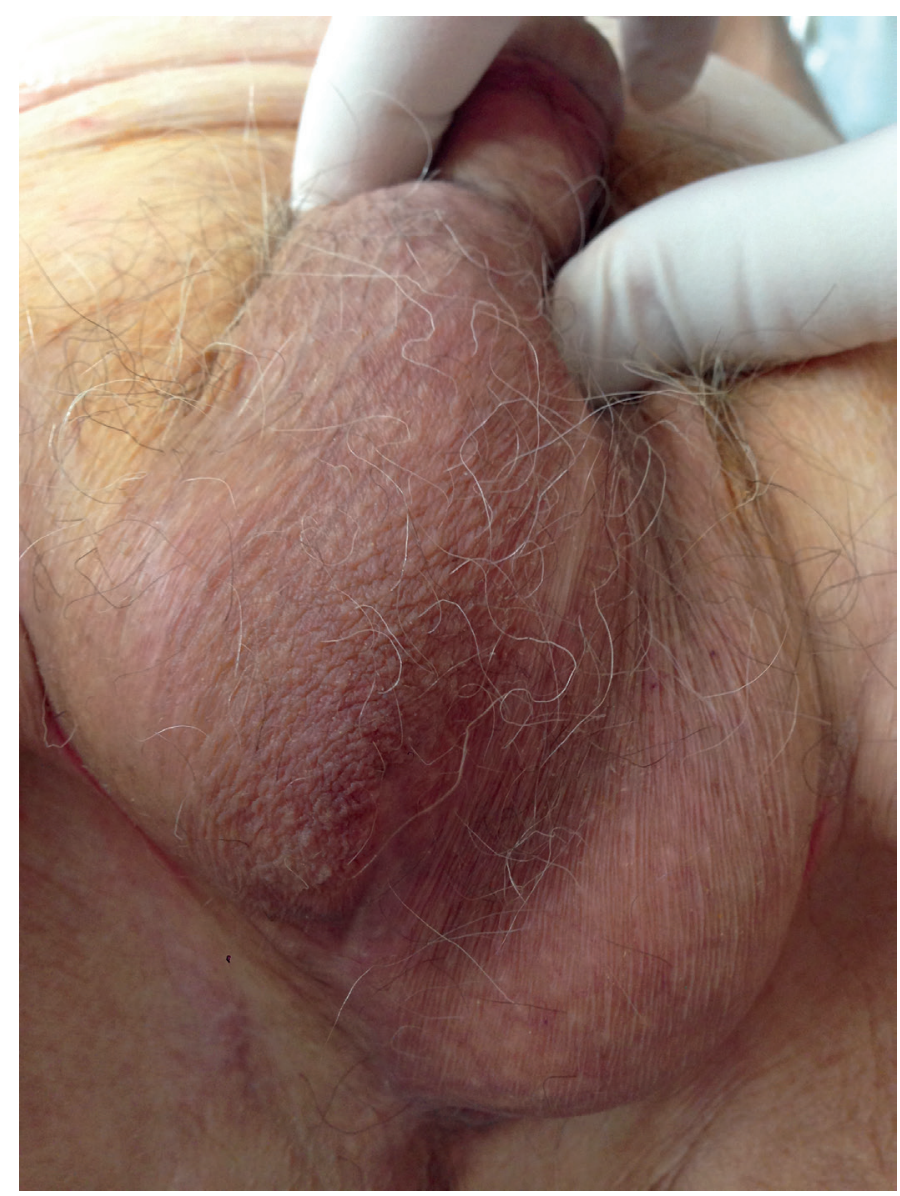

Figure 2 . In postoperative $3^{\text {th }}$ month, there was no necrotic tissue in the scrotal area

was considered to be a late complication of urethral MMC administration.

Intralesional MMC injection has been described as an efficient and reliable treatment method with rare complications. However, although it has not been reported, our case gives an important message to the surgeons that MMC may cause tissue necrosis.

\section{Ethics}

Informed Consent: Written informed consent was obtained from the patient.

Peer-review: Externally peer-reviewed.

\section{Authorship Contributions}

Surgical and Medical Practices: B.T., Concept: B.T., S.Y., Design: B.T., Data Collection or Processing: B.T., S.Y., Analysis or Interpretation: S.U., H.C.I., Literature Search: B.T., S.Y., Writing: B.T.

Conflict of Interest: No conflict of interest was declared by the authors. 
Financial Disclosure: The authors declared that this study received no financial support.

\section{References}

1. Albers $P$, Fichtner J, Brühl $P$, Müler SC. Long-term results of internal urethrotomy. J Urol 1996;156:1611-1614.

2. Singh 0, Gupta SS, Arvind NK. Anterior urethral strictures: a brief review of the current surgical treatment. Urol Int 2011;1:10.

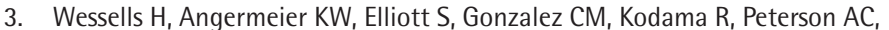
Reston J, Rourke K, Stoffel JT, Vanni AJ, Voelzke BB, Zhao L, Santucci RA. Male Urethral Stricture: American Urological Association Guideline. J Urol 2017;197:182-190.

4. Buckley JC, Heyns C, Gilling P, Carney J. SIU/ICUD Consultation on Urethral Strictures: Dilation, internal urethrotomy, and stenting of male anterior urethral strictures. Urology 2014;83(3 Suppl):18-22.

5. Solsona E, Iborra I, Ricós JV, Monrós JL, Casanova J, Dumont R. Effectiveness of a single immediate mitomycin $\mathrm{C}$ instillation in patients with low risk superficial bladder cancer: short and long-term followup. J Urol 1999;161:1120-1123.

6. Mazdak H, Meshki I, Ghassami F. Effect of mitomycin $\mathrm{C}$ on anterior urethral stricture recurrence after internal urethrotomy. Eur Urol 2007;51:10891092.

7. Böhle A, Jocham D, Bock PR. Intravesical bacillus Calmette-Guerin versus mitomycin C for superficial bladder cancer: a formal meta-analysis of comparative studies on recurrence and toxicity. J Urol 2003;169:90-95.

8. Ferguson B, Gray SD, Thibeault S. Time and dose effects of mitomycin C on extracellular matrix fibroblasts and proteins. Laryngoscope 2005;115:110115.
9. Vanni AJ, Zinman LN, Buckley JC. Radial urethrotomy and intralesional mitomycin $\mathrm{C}$ for the management of recurrent bladder neck contractures. J Urol 2011;186:156-160.

10. Kumar S, Garg N, Singh SK, Mandal AK. Efficacy of Optical Internal Urethrotomy and Intralesional Injection of Vatsala-Santosh PGI Tri-Inject (Triamcinolone, Mitomycin C, and Hyaluronidase) in the Treatment of Anterior Urethral Stricture. Adv Urol 2014;2014:192710.

11. Nicholson HL, Al-Hakeem Y, Maldonado JJ, Tse V. Management of bladder neck stenosis and urethral stricture and stenosis following treatment for prostate cancer. Transl Androl Urol 2017;6(Suppl 2):92-102.

12. Sourial MW, Richard PO, Bettez $M$, Jundi $M$, Tu LM. Mitomycin-C and urethral dilatation: A safe, effective, and minimally invasive procedure for recurrent vesicourethral anastomotic stenoses. Urol Oncol 2017:35:672.

13. Redshaw JD, Broghammer JA, Smith TG, Voelzke BB, Erickson BA, McClung $C D$, Elliott SP, Alsikafi NF, Presson AP, Aberger ME, Craig JR, Brant WO, Myers JB. Intralesional injection of mitomycin $C$ at transurethral incision of bladder neck contracture may offer limited benefit: TURNS Study Group. J Urol 2015;193:587-592.

14. Moradi M, Derakhshandeh K, Karimian B, Fasihi M. Safety and efficacy of Intraurethral Mitomycin $\mathrm{C}$ Hydrogel for prevention of post-traumatic anterior urethral stricture recurrence after internal urethrotomy. J Inj Violence Res 2016;8:75-79.

15. Kumar S, Kishore L, Sharma AP, Garg N, Singh SK. Efficacy of holmium laser urethrotomy and intralesional injection of Santosh PGI tetra-inject (Triamcinolone, Mitomycin $\mathrm{C}$, Hyaluronidase and $\mathrm{N}$-acetyl cysteine) on the outcome of urethral strictures. Cent European J Urol 2015;68:462-465.

16. Ali L, Shahzad M, Orakzai N, Khan I, Ahmad M. Efficacy of mitomycin C in reducing recurrence of anterior urethral stricture after internal optical urethrotomy. Korean J Urol 2015;56:650-655. 